Applied Financial Economics, Volume 18, Issue 17, 2008, Pages 1401-1410

Long-run and Short-run Relationship between the Main Stock Indexes: Evidence from

the Athens Stock Exchange

\author{
Theophano Patra \\ The American College of Greece \\ 6 , Xenias street \\ 11528 , Athens \\ Greece \\ Email: f_patra@acg.gr \\ Sunil Poshakwale* \\ Cranfield School of Management \\ Cranfield University \\ Cranfield, Bedford, MK43 0AL \\ United Kingdom \\ Tel: +44 (0) 1234754404 \\ Fax: +44 (0) 1482752554 \\ Email: sunil.poshakwale@cranfield.ac.uk
}

*Corresponding author 


\title{
Long-run and Short-run Relationship between the Main Stock Indexes: Evidence from the Athens Stock Exchange
}

\begin{abstract}
Evidence on long-run and short-run relationship among the major stock indexes in the highly concentrated Athens stock exchange is provided utilizing daily data for the period 01/01/96 to $31 / 12 / 03$. The findings suggest that even though the sector indexes do not show a consistent and strong long-term relationship, the banking sector seems to have a strong influence on returns and volatility of other sectors at least in the short-run. The variance decomposition analysis confirms that although the variance of returns for most sectors is largely influenced by their own innovations, banking sector is able to explain $25 \%$ of variance of construction and insurance sectors and around $15 \%$ of the variance of industrial, investment and the holding sectors. The leading role of the banking sector implies that changes in the banking sector index could be potentially used in predicting short term movements in other sector indexes confirming that the ASE is not weak form efficient.
\end{abstract}

Key Words: Emerging markets, Athens stock exchange, EMH, Cointegration, Causality. JEL Classification: G11, G14, G15 


\section{Long-run and Short-run Relationship between the Main Stock Indexes: Evidence from the Athens Stock Exchange}

\section{Introduction}

Increasing investors' interest in emerging markets has motivated a spate of research aimed at understanding the return and risk characteristics of stock prices in these markets. Particularly, investors have been keen on identifying any signals of informational inefficiency that could be potentially exploited to make large economic gains. Whilst previous studies have shown that emerging markets are complex and their behaviour is influenced by a number of factors, research on individual emerging markets is considered valuable since it does contribute in furthering our understanding of the factors driving returns and volatility in these fast developing markets (Erb et al., 1997; Poshakwale, 2001). Stock indexes are frequently used in testing for the market efficiency and performance of emerging markets particularly in cases where there is a high market concentration (see, Buguk et al., 2003). Higgins (1988) suggests that examination of the relationship between stock market indexes provides useful information in predicting future economic performance. Further there is evidence that the rejection of weak form market efficiency could be explained by the high correlation amongst the dominant sector indexes (Arbeláez et al., 2001). Amongst others, Ratner (1996) uses nine major equity indices in examining the market efficiency of the Madrid Stock Exchange and confirms that index returns significantly depart from the random walk and their distribution deviate from normality.

Previous research using index data in the Greek stock markets seem to confirm that the Athens Stock Exchange (ASE, henceforth) is informationally inefficient. For example, Kavussanos and Dockery (2001) using multivariate generalizations and seemingly unrelated 
regressions, confirm that the ASE is informationally inefficient, implying that past stock prices contain information for predicting future price movements. Siourounis (2002) employ GARCH type models and tests for their validity in the Athens Stock Exchange Market. He finds that returns are correlated and current volatility is positively correlated with past volatility confirming that the weak form of efficient market hypothesis does not hold in the ASE. Niarchos and Alexakis (2003), test the market efficiency in the ASE by investigating for the stock price patterns. They find that specific price patterns exist and that trading rules based on these price patterns can be profitably exploited compared to a passive buy and hold strategy. More recently, Panagiotidis (2005) rejects the random walk hypothesis for the three different FTSE/ASE indices after the introduction of Euro.

Athens Stock Exchange has 18 sector indices, yet only six sectors namely, Banking, Industrial, Construction, Insurance, Investment and Holding account for more than $63 \%$ of the total market capitalization. We believe that understanding the behaviour and interaction amongst these six main indexes will significantly contribute in understanding the role of major sectors of the Greek economy in shaping the behaviour and efficiency of the Athens Stock Exchange. Furthermore, an investigation of the short and long run relationships amongst the major sectoral indexes will be highly useful to individual and institutional investors who are keen on diversifying their portfolios by investing in the emerging Greek stock market.

The main purpose of this paper is to provide empirical evidence on the short term and long term relationships amongst the major stock indexes of the Athens Stock Exchange. To the best our knowledge this is the first study that examines the short and long run interactions 
among stock indexes in the ASE. The findings of this research will help in answering a number of interesting issues such as: do these indexes behave in similar ways? Do they influence each other in the short and the long run? What is the direction of causality and is this causality consistent over time?

Our findings suggest that even though the sector indexes do not show a consistent and strong long-term relationship, the banking sector seems to have a strong influence on the returns and volatility of other sectors at least in the short-run. The variance decomposition analysis confirms that although the variance of returns for most sectors is largely influenced by their own innovations, banking sector is able to explain $25 \%$ of variance of construction and the insurance sectors and around $15 \%$ of the variance of industrial, investment and holding sectors. The leading role of the banking sector implies that changes in the banking sector index could be potentially used in predicting short term movements in other sector indexes confirming that the ASE is not weak form efficient.

The rest of the paper is organised as follows. The next section describes the data and the methodology. Section 3 reports the results of empirical tests and the last section concludes.

\section{Data and Methodology}

There are 18 sector indexes in the Athens Stock Exchange. For a sector index to be created, it must include at least five companies unless the total average market capitalisation of the sector is at least equal to $3 \%$ of the market value of the ASE in which case a sector index may contain only 3 listed companies. The number of shares making up a sector index must correspond to at least $65 \%$ of the sector's capitalization. The data used in this study consists of daily stock prices of the Banking, Industrial, Construction, Insurance, Investment and Holding 
sector indexes. As already mentioned, only a few sectors dominate the market capitalization and trading in the ASE. For instance, at the end of 2003, Banking, Industrial and Construction sectors together accounted for nearly $54 \%$ of the total market capitalization in the ASE. The remaining 15 sectors shared the balance $46 \%$ market capitalization. For this reason, we have selected the six main indexes representing the Banking, Industrial, Construction, Insurance, Investment and Holding sectors. Table 1 shows the weights of each sector in the ASE General Index, their market capitalization, trading volumes and the number of listed companies for each selected sector. The statistics show that the banking sector leads all other sectors with the highest percentage (27.51\%) of the total market capitalization worth $€ 18.467$ million and trading volume of $€ 5.722$ million. The Banking sector is followed by the Industrial, Holding, Construction, Investment and the Insurance sectors respectively in terms of market capitalization and trading volume. The total weight of these five sectors in the ASE General Index is $63.2 \%$ confirming the highly concentrated nature of the ASE.

Daily data for the period from $01 / 01 / 96$ to $31 / 12 / 03$ comprising 2,088 trading days has been collected. We choose 1996 as the start of our sample period because daily data on the selected sectors is available only from this date. Data series used in this study were obtained from the ASE database. In all cases we have used the logarithmic transformation of the price series in calculating daily returns.

Figure 1 provides a time series plot of the daily return series. A visual inspection of Figure 1 shows an upward trend during 1996-1999 and a downward trend during 2000-2003. Thus there appears to be a clear structural break in the time series which may have been caused by the regulatory changes introduced by the Greek government at the beginning of 2000 . The 
regulatory changes aimed to rationalize and modernise the ASE by introducing changes in the listing requirements, measures for improving the transparency of the market, and new laws for dealing with the modernisation of stock transactions. ${ }^{1}$ We split the total sample into two equal sub-periods to account for this structural break which also reflects the change in the market conditions in the ASE. The first sub-period 1996-1999 represents bull market and the second sub-period 2000-2003 reflects the bear market conditions in the Athens Stock Exchange. ${ }^{2}$

The analytical process comprises four steps. The first step involves determining the order of integration. For this purpose, the unit root testing procedure suggested by Zivot and Andrews (1992) is used because as already seen in figure 1; the time series exhibits a clear structural break. $^{3}$

The second step involves examining the long run relationships using the VAR analysis proposed by Johansen (1988) and Johansen and Juselius (1990). We follow Johansen-Juselius ( $\mathrm{JJ})$ because their approach is considered superior to the regression-based approach suggested by Engle and Granger in 1987 (Cheung and Lai, 1993). ${ }^{4}$ Another reason for using the JJ approach is that it utilizes the maximum likelihood estimates and allows testing and estimation of more than one cointegrating vector in the multivariate system without requiring a specific variable to be normalised. This way, the JJ tests overcome the problem of carrying over the errors from the first step into the second step commonly encountered in Engle and

\footnotetext{
${ }^{1}$ See Law No 2843 in Government Gazette on 21.1.2000

${ }^{2}$ This is consistent with Pricing (1991) who suggests that the stock price formation is different in bull and bear market conditions.

${ }^{3}$ Perron (1988) showed that the augmented Dickey-Fuller and Phillips-Perron test statistics are biased toward the rejection of a unit root test if there is any evidence of structural break(s) in the series.

${ }^{4}$ The Johansen-Juselius procedure resolves the problem of endogeneity in that we do not need to normalise the cointegrating vector on one of the variables as required in the Engle and Granger (EG) test.
} 
Granger's (1987) approach to cointegration. Further, JJ method is independent of the choice of the endogenous variable within a vector autoregression (VAR) framework which enables testing for various structural hypotheses involving restricted versions of cointegrating vectors and speed of adjustment parameters using likelihood ratio tests.

The analysis begins by specifying the vector autoregression model. Following Johansen (1988) and Johansen and Juselius (1990), the VAR representation is written as follows:

$$
Y_{t}=\mu+\prod_{1} Y_{t-1}+\prod_{2} Y_{t-2}+\ldots \ldots \ldots+\prod_{k} Y_{t-k}+e_{t}=\mu+\sum_{j=1}^{k} \prod_{j} Y_{t-j}+e_{t}
$$

where

$$
Y_{t}=\left[\begin{array}{c}
Y_{1 t} \\
Y_{2 t} \\
\vdots \\
Y_{m t}
\end{array}\right] \mu=\left[\begin{array}{c}
\alpha_{10} \\
\alpha_{20} \\
\vdots \\
\alpha_{m 0}
\end{array}\right] \Pi_{k}=\left[\begin{array}{cccc}
\alpha_{11 k} & \alpha_{12 k} & \cdots & \alpha_{1 m k} \\
\alpha_{21 k} & \alpha_{22 k} & \cdots & \alpha_{2 m k} \\
\vdots & \vdots & \vdots & \vdots \\
\alpha_{m 1 k} & \alpha_{m 2 k} & \cdots & \alpha_{m m k}
\end{array}\right] e_{t}=\left[\begin{array}{c}
e_{1 t} \\
e_{2 t} \\
\vdots \\
e_{m k}
\end{array}\right]
$$

The VAR system can be rewritten as the Vector Error Correction Model (VECM) as follows:

$$
\begin{gathered}
\Delta Y_{t}=\mu+\Gamma_{1} \Delta Y_{t-1}+\Gamma_{2} \Delta Y_{t-2}+\ldots \ldots+\Pi Y_{t-k}+e_{t} \\
=\mu+\sum_{i=1}^{k-1} \Gamma_{i} \Delta Y_{t-i}+\Pi Y_{t-k}+e_{t}
\end{gathered}
$$

where

$$
\begin{aligned}
& \Gamma_{i}=-\left[I-\sum_{j=1}^{i} \Pi_{j}\right] \\
& \Pi=-\left[I-\sum_{i=1}^{k} \Pi_{i}\right]
\end{aligned}
$$

The first term in equation (3) captures the short-run effects whereas the second term captures the long-run equilibrium relationship. Since our objective is to investigate the long-run 
relationship, we will focus on the elements of matrix $\Pi$. If vector $\mathrm{Y}$ contains $\mathrm{m}$ variables, matrix $\Pi$ will be of order $\mathrm{m} x \mathrm{~m}$, with a maximum possible rank of $\mathrm{m}$ (or full rank). Equation (3), except for the $\Pi Y_{t-k}$ term, is in the form of the traditional VAR with first difference. The $\Pi$ term determines whether the system of equations is cointegrated, i.e., whether a long-run equilibrium relationship exists. The feature to note is that the rank of matrix $\Pi$ is equal to the number of independent cointegrating vectors. If rank of matrix $\Pi=0$, the matrix is null, i.e., all the elements in this matrix are zero, which implies no cointegration or in other words lack of a long-run equilibrium relationship and the error correction mechanism, $\Pi Y_{t-k}$, therefore, does not exist. In determining the rank of matrix $\Pi$ (number of cointegrating vectors), we calculate the characteristic roots or eigenvalues, $\hat{\lambda}_{i}$ of $\Pi$. Johansen (1988) and Johansen and Juselius (1990) propose trace $\left(\lambda_{\text {trace }}\right)$ and maximum eigenvalue $\left(\lambda_{\max }\right)$ test statistics to establish whether the characteristics roots are significantly different from zero. The computed values of $\lambda_{\text {trace }}$ and $\lambda_{\max }$ statistics are evaluated using the critical values provided by Osterwarld-Lenum (1992) and the optimal system lag length is determined by using the Schwarz Bayesian Criterion (SBC).

If there is no cointegration or long-term relationship between the indexes then the short-term relationship is examined using the Granger causality between the endogenous variables in the following way:

$$
\begin{aligned}
& \mathrm{R}_{\mathrm{y}, \mathrm{t}}=\mathrm{a}+\sum_{i=1}^{n} \beta_{\mathrm{i}} \mathrm{R}_{\mathrm{y}, \mathrm{t}-\mathrm{i}}+\sum_{i=1}^{n} \gamma_{\mathrm{i}} \mathrm{R}_{\mathrm{x}, \mathrm{t}-\mathrm{i}}+\varepsilon_{\mathrm{t}} \\
& \mathrm{R}_{\mathrm{x}, \mathrm{t}}=\mathrm{a}+\sum_{i=1}^{n} \delta_{\mathrm{i}} \mathrm{R}_{\mathrm{x}, \mathrm{t}-\mathrm{i}}+\sum_{i=1}^{n} \zeta_{\mathrm{i}} \mathrm{R}_{\mathrm{y}, \mathrm{t}-\mathrm{l}}+\mathrm{u}_{\mathrm{t}}
\end{aligned}
$$

where $\mathrm{R}_{\mathrm{y}, \mathrm{t}}$ and $\mathrm{R}_{\mathrm{x}, \mathrm{t}}$ are the returns of index $\mathrm{y}$ and $\mathrm{x}$ at time $\mathrm{t}$ accordingly. 
In the above regressions we examine whether the coefficients $\gamma_{\mathrm{i}}$ and $\zeta_{\mathrm{i}}$ are equal to zero using a standard $\mathrm{F}$ test. If $\gamma_{\mathrm{i}}$, and $\zeta_{\mathrm{i}}$ coefficients are different from zero then we conclude that there is a bi-directional causality between and $\mathrm{R}_{\mathrm{y}, \mathrm{t}}$ and $\mathrm{R}_{\mathrm{x}, \mathrm{t}}$. Alternatively, if both coefficients are found to be equal to zero, then we are able to conclude that there is no causality. Finally, in equation (4) $R_{y, t}$ Granger causes $R_{x, t}$ if $\gamma_{i}=0$ for $i=1,2, \ldots n$. Similarly, in (5) causality implies that $\mathrm{R}_{\mathrm{x}, \mathrm{t}}$ Granger causes $\mathrm{R}_{\mathrm{y}, \mathrm{t}}$, provided that $\zeta_{\mathrm{i}} \neq 0$ for $\mathrm{i}=1,2, \ldots \mathrm{n} .^{5}$

The short run dynamics are examined by using the variance decomposition analysis. The variance decomposition traces the relative importance of each random innovation in affecting the variables in the system. Specifically, the forecast-errors provide information about the proportion of the movements caused by own shocks vis a vis shocks in other variables. Since the ordering of variables in the VAR model has a significant impact in variance decomposition results, we follow the order invariant generalised variance decomposition analysis (see, Pesaran and Shin, 1998). Also in contrast to the traditional impulse response analysis (Koop, 1996), the generalised approach does not require orthogonalisation of shocks. The generalised variance decomposition is widely used in studying long and short run linkages across sector indexes (see for example, Wang, Kutan, and Yang, 2005).

\section{Empirical Findings}

Table 2 presents the descriptive statistics of returns for all six sectors. Panel A reports statistics for the whole sample period whilst panel B and C contain statistics for the two subperiods, 1996-1999 and 2000-2003. In panel A, the Industrial sector offers highest average

\footnotetext{
${ }^{5}$ One problem related with the Granger causality test is that results are sensitive with respect to the selected of lag length. We use the Schwarz Bayesian Criterion (SBC) in determining the appropriate lag length because it is considered theoretically superior to the Akaike's Information Criterion (AIC) and penalizes for inclusion of higher number of lags in the regression.
} 
returns and lowest standard deviation. The next best performing sector is the Banking sector with an average daily return of 0.068 . The Construction sector seems to be the most volatile amongst all six sectors with the highest standard deviation of 0.027 . Skewness and kurtosis measures show that return distributions of all six sectors are positively skewed and highly leptokurtic. A similar pattern of return distribution is found for first sub-period in Panel B. However, for second sub-period (Panel C), the returns are negatively skewed for the Industrial sector. Kurtosis is higher than normal for returns in the whole period as well as the two subperiods for all six sectors suggesting that return distributions deviate from the normal distribution. Next we examine the autocorrelations of returns for lags one to five. We have chosen to examine autocorrelations up to five lags because we use daily data and wanted to look as far back as a week. From results (not reported here but available on request) we are able to note that for the period 1996-2003, the first order autocorrelations are statistically significant in all cases. Furthermore, the Box-Pierce Q-statistics suggest that all time series exhibit significant positive autocorrelation at lag one. Autocorrelations for the two subperiods do not show any significant difference relative to those obtained for the full period. Therefore for both sub-periods the null hypothesis of no serial dependence is rejected at $5 \%$ level of significance. We use Zivot and Andrews unit root test (ZA) to determine the order of integration for each series. The ZA test results (not reported here but available on request) show that the null hypothesis of unit root cannot be rejected for any of the indexes in the level form. However, we are able to reject the null hypothesis for the first differenced series for all six sectors at the $1 \%$ level of significance confirming that all six sectors indexes are integrated to the order one, I (1). Results of Johansen's cointegration tests for the full sample and two sub-periods are given in Table 3. Column 1 shows fifteen different models employed in examining the long-run relationships and columns 2 and 3 provide the Trace and Maximum 
Eigenvalue statistics. For the full sample, the results conclusively indicate that the returns of the Banking and the Construction index are cointegrated. ${ }^{6}$ Notably, the indexes appear to show greater cointegration in the second sub-period (1996-2003) where the null hypothesis of no cointegration can be rejected in more number of cases. Specifically, Banking-Investment, Industrial-Insurance, Industrial-Investment, Construction-Investment, Investment-Holding are cointegrated at the 5\% level of significance. The results are consistent with those reported by Wang et al. (2005) for the Chinese stock markets where they find that various sectors are highly integrated and sector prices reflect information from other sectors. The results are also consistent with studies which show that long-run relationships among national equity markets have become stronger over time (see for example, Al-Khazali et al. 2006, Nikkinen, et al. 2006). Overall though, with the exception of Banking and the Construction sectors, the statistical evidence for the long-term equilibrium relationship is neither consistent nor statistically very strong to suggest that there is a long-term relationship among the ASE sectoral indexes.

Since most sectors do not show consistent and strong evidence of a long-run relationship, we examine whether they are related at least in the short-run by using the Granger's causality tests. The results in Table 4 for the full as well as the two sub-periods show that there is unidirectional causality running from Banking to Construction, Insurance, Investment and Holding sectors. This clearly indicates that the banking sector appears to be the most dominant and influential sector in the Greek economy in spite of some evidence of bi-

\footnotetext{
${ }^{6}$ Given that the Banking and Constructions indexes are cointegrated, we use an Error-correction Model (ECM). The results of the ECM (not reported here but available on request) show that for the whole sample as well as the two sub-periods, lagged as well as unlagged innovations in returns from banking index could be potentially used in forecasting returns from the Construction index thus confirming the leading role of the banking sector in the ASE.
} 
directional causality between Construction and Investment sectors and unidirectional causality between Holding and the Investment sectors. Overall though, the F-statistics are significant for only 11 out of 30 combinations which suggest that there is no consistent evidence of bidirectional causality or short-run relationship amongst the sector indexes.

Further analysis of the index returns using the variance decomposition analysis for periods ranging from one, one to five, one to ten, and one to fifteen days presented in Table 5 suggests that for most sector indexes, the forecast variance seems to be most influenced by the innovations in the past variance. The variance decomposition analysis results for the whole sample period (denoted I) as well as the two sub-periods (II and III respectively) further confirm this finding. Specifically, on the first day (short run), for period I, the banking index explains $100 \%$ of its forecast error variance by innovations in its own variance. After fifteen days (long run) $99.5 \%$ of the variation is explained by own innovations while changes in Industrial, Construction, Insurance, Investment, and Holding sectors only explain $0.9 \%, 1.1 \%$, $0.8 \%, 0.2 \%, 0.6 \%$ of the variance in the banking sector respectively. However, the variance decomposition analysis results for other sectors, though largely similar to the banking sector, suggest that innovations in the variance of returns in the banking sector is able to explain, on average, $25 \%$ innovations in the variance of Construction and the Insurance sector. The variance innovations in banking sector returns also seem to influence variance of Industrial, Investment and the Holding sector returns. This is consistent with the evidence of short-term unidirectional causality flowing from the banking sector to the other sectors reported in Table 4.

The leading role of the banking sector in the ASE could be explained by its significance in the Greek economic system. The Greek banking sector index includes National Bank of Greece, 
Alpha Bank, EFG Eurobank Ergasias, Commercial Bank of Greece, and Piraeus Bank. These five banks are dominant players in the Athens stock exchange with a combined market capitalization value of $€ 18.467 \mathrm{~m}$ and $27.51 \%$ share of the total market capitalization of the ASE in 2003. According to the Athens Stock Exchange official reports, the banking sector represents $11 \%$ of the total number of companies listed in the ASE and more than $55 \%$ of the total annual transactions. Further, banks represent about $50 \%$ of the twenty five most active stocks in the ASE (see Athens Stock Exchange yearbook 2003). Thus, higher market capitalisation and greater liquidity of the banking sector stocks is reflected in the leading influence of the banking sector reported in our analysis in the previous sections.

\section{Conclusions}

This paper investigates short and long term relationships amongst the six main indexes of the Athens Stock Exchange with an aim to examine whether the ASE is informationally efficient. The paper analyses daily returns of the Banking, Industrial, Construction, Insurance, Investment and Holding sector indexes over a period of seven years (1996-2003) as well as for the two sub-periods 1996-1999 (representing bull period) and 2000-2003 (representing a bear period). The findings suggest that even though the major sectors do not show a consistent and strong long-term relationship, the banking sector seems to have a strong influence on the returns and volatility of other sectors at least in the short-run. The variance decomposition analysis confirms that although the variance of returns for most sectors is largely influenced by their own return innovations, banking sector is able to explain $25 \%$ of variance of construction and the insurance sectors and around $15 \%$ of the variance of industrial, investment, and holding sectors. The leading role of the banking sector implies that changes in the banking sector index could be potentially used in predicting short term movements in other indexes confirming that the ASE is not weak form efficient. 


\section{References}

Al-Khazali, O., Darrat, A., Saad, M. (2006) Intra-regional integration of the GCC stock markets: the role of market liberalisation, Applied Financial Economics, 16, 17, 1265-1272.

Arbeláez, H., Urrutia, J. and Abbas, N. (2001) Short-term and long-term linkages among the Colombian capital market indexes, International Review of Financial Analysis, 10, 237-373.

Athens Stock Exchange, 1996 to 2003. Yearbooks of the Athens Stock Exchange.

Buguk, C. and Brorsen W.B. (2003) Testing weak-form efficiency: Evidence from the Istanbul Stock Exchange, International Review of Financial Analysis, 12, 5, 579-590.

Cheung Y.M and Lai, K.S. (1993) Finite sample sizes of Johansen's likelihood ratio tests for cointegration, Oxford Bulletin of Economics and Statistics 55, 313-328.

Engle, R. and Granger, C.W.S. (1987) Cointegration and error correction: representation estimation and testing, Econometrica, 55, 251-276.

Erb, C.B., Harvey, C.R. and Viskanta, T.E. (1997) The making of an emerging market, Emerging Market Quarterly, 1, 14-19.

Higgins, B. (1988) Is a recession inevitable this year? Economic Review, 73, 1, Federal Reserve Bank of Kansas City, January, 3-16.

Johansen, S. (1988) Statistical analysis of cointegration vectors, Journal of Economic Dynamics and Control, 12, 231-254.

Johansen, S. and Juselius, K. (1990). Maximum likelihood estimation and inference on cointegration with applications to the demand of money. Oxford Bulletin of Economics and Statistics, 52, 169-210.

Kavussanos, M.G and Dockery, E. (2001) A multivariate test for stock market efficiency: the case of ASE. Applied Financial Economics, 5, 573- 584.

Koop,G., Perasan, M.H., and Potter, S.M. (1996) Impulse response analysis in nonlinear multivariate models. Journal of Econometrics, 74, 119-147.

Niarchos, N.A.and Alexakis, C.A. (2003) Intraday stock price patterns in the Greek stock exchange. Applied Financial Economics, 1, 13-22. 
Nikkinen, J., Omran, M., Sahlstrom, P., Aijo, J. (2006) Global stock market reactions to scheduled U.S. macroeconomic news announcements. Global Finance Journal, 17, 1, 92-104.

Panagiotidis, T. (2005) Market capitalisation and efficiency. Does it matter? Evidence from the Athens stock exchange. Applied Financial Economics 15, 707-713.

Pesaran, H. and Shin Y. (1998) Generalised impulse response analysis in linear multivariate models. Economic Letters, 58, 1, 17-29.

Perron, P. (1988) Trends and random walks in macroeconomic time series: further evidence from a new approach. Journal of Economic Dynamics and Control, 12, 297-332.

Poshakwale. S. (2001) Foreign Equity Investment, Market Segmentation and Volatility in the Emerging Chinese Stock Markets. China Accounting and Finance Review, 3, 1, 137-166.

Pricing, C. (1991) The predictability of security returns with simple technical trading rules. Journal of Empirical Finance, 10, 348-359.

Ratner, M. (1996) Investigating the behaviour and characteristics of the Madrid stock exchange. Journal of Banking and Finance, 20, 135-149.

Siourounis, G.D. (2002) Modelling volatility and test for efficiency in emerging capital markets: the case of the Athens stock exchange, Applied Financial Economics, 1, 47-55.

Wang, Z., Kutan, A., Yang, J. (2005) Information within and across sectors in Chinese stock markets. The Quarterly Review of Economics and Finance, 45, 4-5, 767-780.

Zivot, E. and Andrews, D.W.K. (1992) Further evidence on the great crash, the oil price shock, and the unit-root hypothesis. Journal of Business and Economic Statistics, 3, 251-270. 
Table 1: A.S.E Sector Indices (2003)

\begin{tabular}{|lccrc|}
\hline Index & $\begin{array}{c}\text { Weight in } \\
\text { General Index }(\%)\end{array}$ & $\begin{array}{c}\text { Market } \\
\text { Capitalisation }\end{array}$ & $\begin{array}{c}\text { Trading } \\
\text { Volume }\end{array}$ & $\begin{array}{c}\text { Number of } \\
\text { Firms }\end{array}$ \\
\hline Banking & 27.51 & 18.467 & 5.722 & 5 \\
Industrial & 22.41 & 13.040 & 2.746 & 19 \\
Construction & 3.85 & 1.389 & 756 & 5 \\
Insurance & 2.99 & 323 & 108 & 3 \\
Investment & 2.93 & 417 & 112 & 4 \\
Holding & 3.51 & 3.008 & 1.019 & 5 \\
\hline
\end{tabular}

Note: Market capitalisation and trading volume are reported in million Euros

Figure 1: Logarithm of Daily Stock Indices, 1996-2003

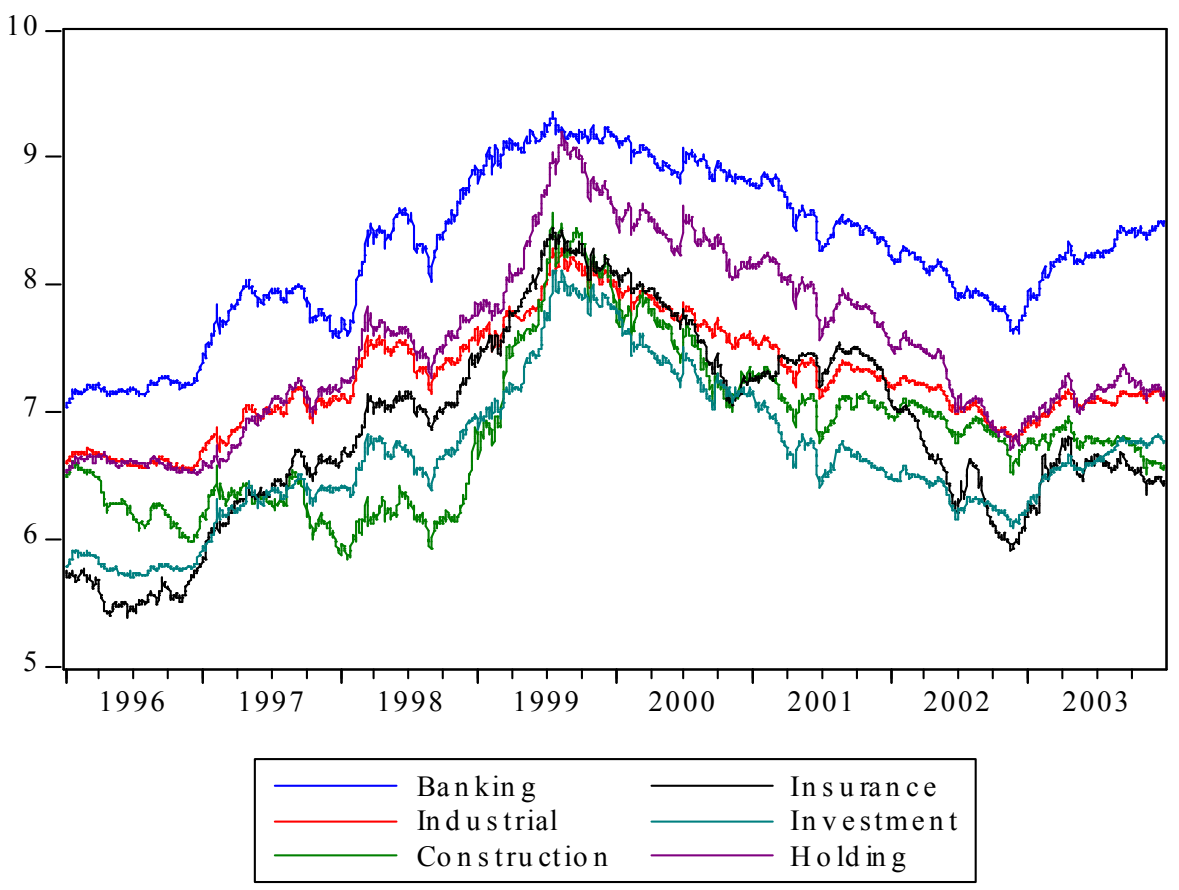

Table 2: Index Return Preliminary Statistics

\begin{tabular}{|c|c|c|c|c|}
\hline Index & Mean & Std. Deviation & Skewness & Kurtosis \\
\hline \multicolumn{5}{|c|}{ Panel A: time period 1996-2003 } \\
\hline Banking & 0.068 & 0.020 & 0.196 & 5.633 \\
\hline Industrial & 0.074 & 0.018 & 0.071 & 5.840 \\
\hline Construction & 0.001 & 0.027 & 0.096 & 4.586 \\
\hline Insurance & 0.035 & 0.022 & 0.175 & 5.291 \\
\hline Investment & 0.045 & 0.020 & 0.174 & 6.182 \\
\hline Holding & 0.031 & 0.022 & 0.001 & 4.554 \\
\hline \multicolumn{5}{|c|}{ Panel B: time period 1996-1999 } \\
\hline Banking & 0.081 & 0.022 & 0.067 & 4.816 \\
\hline Industrial & 0.086 & 0.020 & 0.091 & 5.112 \\
\hline Construction & 0.013 & 0.029 & 0.025 & 3.732 \\
\hline Insurance & 0.019 & 0.022 & 0.041 & 4.080 \\
\hline Investment & 0.020 & 0.022 & 0.018 & 5.243 \\
\hline Holding & 0.001 & 0.021 & 0.023 & 4.198 \\
\hline
\end{tabular}


Panel C: time period 2000-2003

\begin{tabular}{|c|c|c|c|c|}
\hline Banking & 0.088 & 0.019 & 0.389 & 6.010 \\
\hline Industrial & 0.093 & 0.018 & -0.031 & 5.672 \\
\hline Construction & 0.012 & 0.028 & 0.134 & 4.658 \\
\hline Insurance & 0.078 & 0.023 & 0.250 & 5.724 \\
\hline Investment & 0.011 & 0.021 & 0.296 & 6.055 \\
\hline Holding & 0.053 & 0.024 & 0.065 & 4.330 \\
\hline
\end{tabular}

Table 3: Results of the Johansen and Juselius Coint egration Tests

\begin{tabular}{|c|c|c|c|c|c|c|c|}
\hline \multirow{2}{*}{\multicolumn{2}{|c|}{ Index Pairs }} & \multicolumn{2}{|c|}{$1996-2003$} & \multicolumn{2}{|c|}{$1996-1999$} & \multicolumn{2}{|c|}{$2000-2003$} \\
\hline & & Trace & Max. Eigen & Trace & Max. Eigen. & Trace & Max. Eigen. \\
\hline \multirow[t]{3}{*}{1} & Banking - Industrial & & & & & & \\
\hline & $\mathrm{H}_{0}: \tau=0$ & 6.354 & 4.316 & 4.503 & 3.808 & 5.189 & 5.145 \\
\hline & $\mathrm{H}_{0}: \tau \leq 1$ & 2.027 & 2.027 & 0.694 & 0.694 & 0.044 & 0.044 \\
\hline \multirow[t]{3}{*}{2} & Banking - Construction & & & & & & \\
\hline & $\mathrm{H}_{0}: \tau=0$ & $17.691^{* *}$ & $14.947^{* *}$ & $15.546^{*}$ & $15.814^{*}$ & $16.189^{*}$ & $15.145^{*}$ \\
\hline & $\mathrm{H}_{0}: \tau \leq 1$ & $6.148^{* *}$ & $6.148^{* *}$ & $4.137^{*}$ & $4.137^{*}$ & 0.044 & 0.044 \\
\hline \multirow[t]{3}{*}{3} & Banking - Insurance & & & & & & \\
\hline & $\mathrm{H}_{0}: \tau=0$ & 5.726 & 4.176 & 7.798 & 7.721 & 3.895 & 3.730 \\
\hline & $\mathrm{H}_{0}: \tau \leq 1$ & 1.579 & 1.579 & 0.077 & 0.077 & 0.165 & 0.165 \\
\hline \multirow[t]{3}{*}{4} & Banking - Investment & & & & & & \\
\hline & $\mathrm{H}_{0}: \tau=0$ & 8.438 & 5.789 & 6.277 & 5.007 & $16.793^{*}$ & $15.078^{*}$ \\
\hline & $\mathrm{H}_{0}: \tau \leq 1$ & 2.649 & 2.649 & 1.270 & 1.270 & 0.715 & 0.715 \\
\hline \multirow[t]{3}{*}{5} & Banking - Holding & & & & & & \\
\hline & $\mathrm{H}_{0}: \tau=0$ & 8.199 & 5.058 & 5.916 & 5.067 & 4.603 & 4.202 \\
\hline & $\mathrm{H}_{0}: \tau \leq 1$ & 3.140 & 3.140 & 0.849 & 0.849 & 0.401 & 0.401 \\
\hline \multirow[t]{3}{*}{6} & Industrial - Construction & & & & & & \\
\hline & $\mathrm{H}_{0}: \tau=0$ & 11.573 & 6.851 & 4.760 & 4.266 & 6.156 & 5.549 \\
\hline & $\mathrm{H}_{0}: \tau \leq 1$ & 3.721 & 3.721 & 0.494 & 0.494 & 0.615 & 0.615 \\
\hline \multirow[t]{3}{*}{7} & Industrial - Insurance & & & & & & \\
\hline & $\mathrm{H}_{0}: \tau=0$ & 12.846 & 10.949 & 10.550 & 9.907 & $17.488^{*}$ & $15.273^{*}$ \\
\hline & $\mathrm{H}_{0}: \tau \leq 1$ & 1.897 & 1.897 & 0.643 & 0.643 & 0.004 & 0.004 \\
\hline \multirow[t]{3}{*}{8} & Industrial - Investment & & & & & & \\
\hline & $\mathrm{H}_{0}: \tau=0$ & 7.735 & 5.241 & 10.427 & 12.015 & $15.631^{*}$ & $15.541^{*}$ \\
\hline & $\mathrm{H}_{0}: \tau \leq 1$ & 2.493 & 2.493 & 0.032 & 0.032 & 0.089 & 0.089 \\
\hline \multirow[t]{3}{*}{9} & Industrial - Holding & & & & & & \\
\hline & $\mathrm{H}_{0}: \tau=0$ & 15.299 & 12.483 & 7.337 & 7.335 & 12.773 & 11.209 \\
\hline & $\mathrm{H}_{0}: \tau \leq 1$ & 2.815 & 2.815 & 0.002 & 0.002 & 1.563 & 1.563 \\
\hline \multirow[t]{3}{*}{10} & Construction - Insurance & & & & & & \\
\hline & $\mathrm{H}_{0}: \tau=0$ & 8.280 & 7.994 & 6.581 & 5.054 & 9.254 & 7.437 \\
\hline & $\mathrm{H}_{0}: \tau \leq 1$ & 0.286 & 0.286 & 1.526 & 1.526 & 1.816 & 1.816 \\
\hline \multirow[t]{3}{*}{11} & Construction - Investment & & & & & & \\
\hline & $\mathrm{H}_{0}: \tau=0$ & 6.142 & 5.064 & 3.785 & 3.746 & $15.571^{*}$ & $15.119^{*}$ \\
\hline & $\mathrm{H}_{0}: \tau \leq 1$ & 1.078 & 1.078 & 0.038 & 0.038 & 0.151 & 0.151 \\
\hline \multirow[t]{3}{*}{12} & Construction - Holding & & & & & & \\
\hline & $\mathrm{H}_{0}: \tau=0$ & 7.730 & 4.549 & 3.737 & 3.658 & 7.587 & 6.160 \\
\hline & $\mathrm{H}_{0}: \tau \leq 1$ & 3.181 & 3.181 & 0.078 & 0.078 & 1.426 & 1.426 \\
\hline \multirow[t]{3}{*}{13} & Insurance - Investment & & & & & & \\
\hline & $\mathrm{H}_{0}: \tau=0$ & 5.718 & 4.177 & 12.203 & 11.830 & 9.149 & 8.399 \\
\hline & $\mathrm{H}_{0}: \tau \leq 1$ & 1.541 & 1.541 & 0.373 & 0.373 & 0.743 & 0.743 \\
\hline
\end{tabular}

14 Insurance - Holding 


\begin{tabular}{lrrrrrr}
$\mathrm{H}_{0}: \tau=0$ & 7.606 & 7.240 & 10.487 & 10.274 & 7.609 & 5.133 \\
$\mathrm{H}_{0}: \tau \leq 1$ & 0.185 & 0.185 & 0.213 & 0.213 & 2.495 & 2.495 \\
\hline 15 Investment - Holding & & & & & & \\
\\
$\mathrm{H}_{0}: \tau=0$ & 9.104 & 6.141 & 5.880 & 5.835 & $15.690^{*}$ & $14.845^{*}$ \\
$\mathrm{H}_{0}: \tau \leq 1$ & 2.963 & 2.963 & 0.045 & 0.045 & 2.844 & 2.844 \\
\hline
\end{tabular}

Note: $*=$ Significant at $5 \%$ level, $* *=$ Significant at $1 \%$ level

Table 4: Results of the Granger Causality Results

\begin{tabular}{|c|c|c|c|c|c|}
\hline \multirow{2}{*}{\multicolumn{2}{|c|}{ Direction of Causality }} & \multicolumn{3}{|c|}{ F statistic } & \multirow[b]{2}{*}{ Causal Inference } \\
\hline & & $1996-2003$ & 1996-1999 & $2000-2003$ & \\
\hline \multirow[t]{2}{*}{1} & Banking $\longrightarrow$ Industrial & 0.494 & 0.679 & 1.260 & No Causality \\
\hline & Industrial $\longrightarrow$ Banking & 0.065 & 1.613 & 0.501 & No Causality \\
\hline \multirow[t]{2}{*}{2} & Banking $\longrightarrow$ Construction & $3.554^{* *}$ & $2.864^{* *}$ & $3.736^{* *}$ & $\mathrm{Y}$ causes $\mathrm{X}$ \\
\hline & Construction $\longrightarrow$ Banking & 0.450 & 0.706 & 0.569 & No Causality \\
\hline \multirow[t]{2}{*}{3} & Banking $\longrightarrow$ Insurance & $3.370^{* *}$ & $2.796^{* *}$ & $4.375^{*}$ & $Y$ causes $\mathrm{X}$ \\
\hline & Insurance $\longrightarrow$ Banking & 0.543 & 1.952 & 0.038 & No Causality \\
\hline \multirow[t]{2}{*}{4} & Banking $\longrightarrow$ Investment & $3.886^{*}$ & $4.312^{*}$ & $3.291^{*}$ & $Y$ causes $\mathrm{X}$ \\
\hline & Investment $\longrightarrow$ Banking & 0.248 & 1.612 & 0.444 & No Causality \\
\hline \multirow[t]{2}{*}{5} & Banking $\longrightarrow$ Holding & $4.554^{*}$ & $5.075^{*}$ & $3.623^{*}$ & $Y$ causes $\mathrm{X}$ \\
\hline & Holding $\longrightarrow$ Banking & 0.022 & 1.924 & 1.710 & No Causality \\
\hline \multirow[t]{2}{*}{6} & Industrial $\longrightarrow$ Construction & 1.608 & 1.698 & 0.592 & No Causality \\
\hline & Construction $\longrightarrow$ Industrial & 1.176 & 0.725 & 0.736 & No Causality \\
\hline \multirow[t]{2}{*}{7} & Industrial $\longrightarrow$ Insurance & 0.377 & 1.516 & 1.156 & No Causality \\
\hline & Insurance $\longrightarrow$ Industrial & 0.744 & 1.946 & 0.968 & No Causality \\
\hline \multirow[t]{2}{*}{8} & Industrial $\longrightarrow$ Investment & $2.723^{* *}$ & $4.133^{*}$ & $2.541^{* *}$ & Bi-directional \\
\hline & Investment $\longrightarrow$ Industrial & $5.222^{*}$ & $5.580^{*}$ & $2.439^{* *}$ & Bi-directional \\
\hline \multirow[t]{2}{*}{9} & Industrial $\longrightarrow$ Holding & $5.777^{*}$ & $4.275^{*}$ & $2.968^{* *}$ & $Y$ causes $X$ \\
\hline & Holding $\longrightarrow$ Industrial & 1.378 & 1.777 & 0.652 & No Causality \\
\hline \multirow[t]{2}{*}{10} & Construction $\longrightarrow$ Insurance & 0.606 & 1.236 & 1.392 & No Causality \\
\hline & Insurance $\longrightarrow$ Construction & 1.803 & 0.436 & 1.601 & No Causality \\
\hline \multirow[t]{2}{*}{11} & Construction $\longrightarrow$ Investment & $4.154^{*}$ & $3.906^{*}$ & $2.521^{* *}$ & Bi-directional \\
\hline & Investment $\rightarrow$ Construction & $3.505^{*}$ & $2.518^{* *}$ & $3.140^{* *}$ & Bi-directional \\
\hline \multirow[t]{2}{*}{12} & Construction $\longrightarrow$ Holding & 1.760 & 0.521 & 1.109 & No Causality \\
\hline & Holding $\rightarrow$ Construction & $3.940^{*}$ & $3.383^{*}$ & $2.639^{* *}$ & $\mathrm{X}$ causes $\mathrm{Y}$ \\
\hline \multirow[t]{2}{*}{13} & Insurance $\longrightarrow$ Investment & 1.015 & 1.432 & 1.683 & No Causality \\
\hline & Investment $\longrightarrow$ Insurance & 1.576 & 1.281 & 1.784 & No Causality \\
\hline \multirow[t]{2}{*}{14} & Insurance $\longrightarrow$ Holding & 1.448 & 0.789 & 1.351 & No Causality \\
\hline & Holding $\longrightarrow$ Insurance & 1.216 & 1.346 & 1.312 & No Causality \\
\hline \multirow[t]{2}{*}{15} & Investment $\longrightarrow$ Holding & 0.774 & 1.823 & 1.065 & No Causality \\
\hline & Holding $\longrightarrow$ Investment & $5.897^{*}$ & $3.731^{*}$ & $3.924^{*}$ & $\mathrm{X}$ causes $\mathrm{Y}$ \\
\hline
\end{tabular}

Notes: $*=$ Significant at $5 \%$ level, $* *=$ Significant at $1 \%$ level 
Table 5: Results of the Generalised Variance Decomposition Analysis

\begin{tabular}{|c|c|c|c|c|c|c|c|c|c|c|}
\hline & \multirow[b]{3}{*}{ Period } & \multicolumn{9}{|c|}{ Explained by } \\
\hline & & \multicolumn{3}{|c|}{ Banking } & \multicolumn{3}{|c|}{ Industrial } & \multicolumn{3}{|c|}{ Construction } \\
\hline & & I & II & III & I & II & III & I & II & III \\
\hline Banking & $\begin{array}{l}1 \\
5 \\
10 \\
15\end{array}$ & $\begin{array}{l}100 \\
99.5 \\
99.5 \\
99.5\end{array}$ & $\begin{array}{l}100 \\
98.7 \\
98.7 \\
98.7\end{array}$ & $\begin{array}{l}100 \\
99.6 \\
97.7 \\
94.9\end{array}$ & $\begin{array}{l}0 \\
0.2 \\
0.5 \\
0.9\end{array}$ & $\begin{array}{l}0 \\
0.1 \\
0.6 \\
0.6\end{array}$ & $\begin{array}{l}0 \\
0.1 \\
0.4 \\
0.9\end{array}$ & $\begin{array}{l}0 \\
0.7 \\
0.2 \\
1.1\end{array}$ & $\begin{array}{l}0 \\
0.1 \\
1.2 \\
1.4\end{array}$ & $\begin{array}{l}0 \\
0.7 \\
0.5 \\
0.1\end{array}$ \\
\hline Industrial & $\begin{array}{l}1 \\
5 \\
10 \\
15\end{array}$ & $\begin{array}{l}12.5 \\
11.4 \\
11.5 \\
11.0\end{array}$ & $\begin{array}{l}13.6 \\
12.0 \\
12.4 \\
12.5\end{array}$ & $\begin{array}{l}15.3 \\
14.8 \\
12.4 \\
18.8\end{array}$ & $\begin{array}{l}78.5 \\
78.4 \\
78.6 \\
78.0\end{array}$ & $\begin{array}{l}72.5 \\
72.1 \\
72.6 \\
72.6\end{array}$ & $\begin{array}{l}74.6 \\
75.2 \\
77.0 \\
78.4\end{array}$ & $\begin{array}{l}15.0 \\
15.8 \\
15.4 \\
15.4\end{array}$ & $\begin{array}{l}9.4 \\
9.9 \\
9.6 \\
9.3\end{array}$ & $\begin{array}{l}0 \\
0.2 \\
0.1 \\
0.3\end{array}$ \\
\hline Construction & $\begin{array}{l}1 \\
5 \\
10 \\
15\end{array}$ & $\begin{array}{l}25.3 \\
23.8 \\
23.5 \\
23.2\end{array}$ & $\begin{array}{l}28.1 \\
25.3 \\
25.5 \\
25.7\end{array}$ & $\begin{array}{l}29.9 \\
27.4 \\
24.7 \\
22.1\end{array}$ & $\begin{array}{l}0 \\
0.2 \\
0.4 \\
0.2\end{array}$ & $\begin{array}{l}0 \\
0.7 \\
0.9 \\
1.0\end{array}$ & $\begin{array}{l}2.1 \\
3.9 \\
7.6 \\
3.0\end{array}$ & $\begin{array}{l}74.6 \\
75.0 \\
75.5 \\
74.1\end{array}$ & $\begin{array}{l}71.8 \\
72.9 \\
72.0 \\
72.2\end{array}$ & $\begin{array}{l}77.8 \\
78.4 \\
77.2 \\
75.1\end{array}$ \\
\hline Insurance & $\begin{array}{l}1 \\
5 \\
10 \\
15\end{array}$ & $\begin{array}{l}28.4 \\
28.1 \\
28.2 \\
28.8\end{array}$ & $\begin{array}{l}23.9 \\
23.4 \\
23.7 \\
22.1\end{array}$ & $\begin{array}{l}26.9 \\
23.9 \\
21.2 \\
28.9\end{array}$ & $\begin{array}{l}1.6 \\
1.8 \\
1.2 \\
1.0\end{array}$ & $\begin{array}{l}1.4 \\
1.9 \\
1.2 \\
1.8\end{array}$ & $\begin{array}{l}5.4 \\
6.5 \\
6.1 \\
5.7\end{array}$ & $\begin{array}{l}3.8 \\
4.4 \\
4.9 \\
4.7\end{array}$ & $\begin{array}{l}3.7 \\
4.0 \\
4.6 \\
4.3\end{array}$ & $\begin{array}{l}0.1 \\
0.3 \\
0.4 \\
0.5\end{array}$ \\
\hline Investment & $\begin{array}{l}1 \\
5 \\
10 \\
15\end{array}$ & $\begin{array}{l}12.0 \\
11.9 \\
11.5 \\
11.8\end{array}$ & $\begin{array}{l}15.9 \\
15.4 \\
15.5 \\
15.8\end{array}$ & $\begin{array}{l}17.8 \\
19.9 \\
16.2 \\
10.2\end{array}$ & $\begin{array}{l}2.5 \\
2.7 \\
2.4 \\
2.2\end{array}$ & $\begin{array}{l}1.9 \\
2.1 \\
2.2 \\
2.18\end{array}$ & $\begin{array}{l}9.3 \\
10.2 \\
11.1 \\
12.6\end{array}$ & $\begin{array}{c}0.3 \\
11.5 \\
11.4 \\
11.2\end{array}$ & $\begin{array}{l}6.9 \\
7.6 \\
7.3 \\
7.5\end{array}$ & $\begin{array}{l}1.5 \\
1.8 \\
1.0 \\
0.7\end{array}$ \\
\hline Holding & $\begin{array}{l}1 \\
5 \\
10 \\
15 \\
\end{array}$ & $\begin{array}{l}15.1 \\
14.4 \\
14.8 \\
14.2 \\
\end{array}$ & $\begin{array}{l}10.9 \\
19.8 \\
19.5 \\
19.6 \\
\end{array}$ & $\begin{array}{c}14.1 \\
14.7 \\
11.8 \\
8.9 \\
\end{array}$ & $\begin{array}{l}0 \\
0.6 \\
0.4 \\
0.8 \\
\end{array}$ & $\begin{array}{l}0 \\
0.4 \\
0.3 \\
0.2 \\
\end{array}$ & $\begin{array}{l}17.8 \\
21.8 \\
22.6 \\
22.9 \\
\end{array}$ & $\begin{array}{l}17.4 \\
18.7 \\
18.9 \\
18.3 \\
\end{array}$ & $\begin{array}{l}12.1 \\
13.3 \\
13.6 \\
13.2 \\
\end{array}$ & $\begin{array}{l}2.4 \\
2.3 \\
2.1 \\
1.8 \\
\end{array}$ \\
\hline & & \multicolumn{9}{|c|}{ Explained by } \\
\hline & & \multicolumn{3}{|c|}{ Insurance } & \multicolumn{3}{|c|}{ Investment } & \multicolumn{3}{|c|}{ Holding } \\
\hline & Period & I & II & III & I & II & III & $\mathrm{I}$ & II & III \\
\hline Banking & $\begin{array}{l}1 \\
5 \\
10 \\
15\end{array}$ & $\begin{array}{l}0 \\
0.1 \\
0.3 \\
0.8\end{array}$ & $\begin{array}{l}0 \\
0.4 \\
0.3 \\
1.1\end{array}$ & $\begin{array}{l}0 \\
0.3 \\
0.1 \\
0.4\end{array}$ & $\begin{array}{l}0 \\
0.1 \\
0.4 \\
0.2\end{array}$ & $\begin{array}{l}0 \\
0.4 \\
0.3 \\
0.3\end{array}$ & $\begin{array}{l}0 \\
0.2 \\
1.6 \\
4.2\end{array}$ & $\begin{array}{l}0 \\
0.2 \\
0.5 \\
0.6\end{array}$ & $\begin{array}{l}0 \\
0.1 \\
0.8 \\
0.9\end{array}$ & $\begin{array}{l}0 \\
0.2 \\
0.3 \\
0.9\end{array}$ \\
\hline Industrial & $\begin{array}{l}1 \\
5 \\
10 \\
15\end{array}$ & $\begin{array}{l}0 \\
0.5 \\
0.7 \\
0.1\end{array}$ & $\begin{array}{l}0 \\
0.4 \\
0.5 \\
0.1\end{array}$ & $\begin{array}{l}0 \\
0.9 \\
0.5 \\
0.3\end{array}$ & $\begin{array}{l}0 \\
0.1 \\
0.6 \\
0.2\end{array}$ & $\begin{array}{l}0 \\
1.2 \\
1.2 \\
1.8\end{array}$ & $\begin{array}{l}0 \\
0.9 \\
0.8 \\
2.0\end{array}$ & $\begin{array}{l}3.8 \\
3.9 \\
3.7 \\
3.3\end{array}$ & $\begin{array}{l}4.3 \\
4.8 \\
4.9 \\
4.3\end{array}$ & $\begin{array}{l}0 \\
0.1 \\
0.1 \\
0.3\end{array}$ \\
\hline Construction & $\begin{array}{l}1 \\
5 \\
10 \\
15\end{array}$ & $\begin{array}{l}0 \\
0.2 \\
0.9 \\
0.1\end{array}$ & $\begin{array}{l}0 \\
0.1 \\
0.3 \\
0.7\end{array}$ & $\begin{array}{l}0 \\
0.1 \\
0.8 \\
0.2\end{array}$ & $\begin{array}{l}0 \\
0.2 \\
0.6 \\
0.2\end{array}$ & $\begin{array}{l}0 \\
0.7 \\
0.5 \\
0.2\end{array}$ & $\begin{array}{l}0 \\
0.4 \\
0.7 \\
1.2\end{array}$ & $\begin{array}{l}0 \\
0.8 \\
0.1 \\
0.1\end{array}$ & $\begin{array}{l}0 \\
0.7 \\
0.1 \\
0.8\end{array}$ & $\begin{array}{l}0 \\
0.1 \\
0.8 \\
0.9\end{array}$ \\
\hline Insurance & $\begin{array}{l}1 \\
5 \\
10 \\
15\end{array}$ & $\begin{array}{l}64.2 \\
63.2 \\
63.2 \\
63.2\end{array}$ & $\begin{array}{l}69.6 \\
68.2 \\
68.7 \\
68.6\end{array}$ & $\begin{array}{l}67.4 \\
68.9 \\
71.1 \\
72.7\end{array}$ & $\begin{array}{l}0 \\
0.4 \\
0.6 \\
0.8\end{array}$ & $\begin{array}{l}0 \\
0.4 \\
0.3 \\
0.1\end{array}$ & $\begin{array}{l}0 \\
0.1 \\
0.3 \\
0.9\end{array}$ & $\begin{array}{l}1.9 \\
1.8 \\
1.6 \\
1.8\end{array}$ & $\begin{array}{l}1.3 \\
1.5 \\
1.2 \\
1.4\end{array}$ & $\begin{array}{l}0 \\
0.1 \\
0.4 \\
1.0\end{array}$ \\
\hline Investment & $\begin{array}{l}1 \\
5 \\
10 \\
15\end{array}$ & $\begin{array}{l}0.2 \\
0.9 \\
0.1 \\
0.8\end{array}$ & $\begin{array}{l}0.5 \\
0.9 \\
0.2 \\
0.8\end{array}$ & $\begin{array}{l}0.1 \\
0.1 \\
0.2 \\
0.5\end{array}$ & $\begin{array}{l}72.9 \\
71.6 \\
71.3 \\
71.2\end{array}$ & $\begin{array}{l}72.3 \\
71.6 \\
71.4 \\
71.6\end{array}$ & $\begin{array}{l}71.1 \\
67.7 \\
72.6 \\
76.1\end{array}$ & $\begin{array}{l}1.9 \\
2.9 \\
2.9 \\
2.8\end{array}$ & $\begin{array}{l}2.7 \\
3.1 \\
3.2 \\
3.5\end{array}$ & $\begin{array}{l}0 \\
0.5 \\
0.7 \\
2.2\end{array}$ \\
\hline Holding & $\begin{array}{l}1 \\
5 \\
10 \\
15 \\
\end{array}$ & $\begin{array}{l}0 \\
0.1 \\
0.7 \\
0.2 \\
\end{array}$ & $\begin{array}{l}0 \\
0.1 \\
0.9 \\
0.5 \\
\end{array}$ & $\begin{array}{l}0.2 \\
0.3 \\
0.6 \\
1.2 \\
\end{array}$ & $\begin{array}{l}0 \\
0.1 \\
0.1 \\
0.6 \\
\end{array}$ & $\begin{array}{l}0 \\
0.4 \\
0.8 \\
0.2 \\
\end{array}$ & $\begin{array}{l}0 \\
0.1 \\
0.4 \\
1.3 \\
\end{array}$ & $\begin{array}{l}67.4 \\
66.2 \\
66.9 \\
66.2 \\
\end{array}$ & $\begin{array}{l}76.9 \\
75.6 \\
75.7 \\
75.2 \\
\end{array}$ & $\begin{array}{l}75.2 \\
70.6 \\
71.9 \\
63.7 \\
\end{array}$ \\
\hline
\end{tabular}

